\title{
A Case of Multiple Sialolithiasis in the Parotid Gland with Sjögren's Syndrome
}

\author{
Yeong Joon Kim ${ }^{1}$, Hyoung Shin Lee ${ }^{1}$, Seon Yoon $\mathrm{Choi}^{2}$, and Sung Won Kim ${ }^{1}$ \\ ${ }^{1}$ Departments of Otolaryngology-Head and Neck Surgery, ${ }^{2}$ Internal Medicine, Kosin University College of Medicine, Busan, Korea
}

\author{
쇼그렌 증후군과 동반된 다발성 이하선 타석증 1 예 \\ 김영준 $^{1} \cdot$ 이형신 $^{1} \cdot$ 최선윤 ${ }^{2} \cdot$ 김성원 $^{1}$ \\ 고신대학교 의과대학 이비인후과학교실, ${ }^{1}$ 내과학교실 ${ }^{2}$
}

\author{
Received August 1, 2014 \\ Revised October 23, 2014 \\ Accepted October 28, 2014 \\ Address for correspondence \\ Sung Won Kim, MD \\ Department of Otolaryngology- \\ Head and Neck Surgery, \\ Kosin University College of Medicine, \\ 262 Gamcheon-ro, Seo-gu, \\ Busan 602-702, Korea \\ Tel $+82-51-990-6711$ \\ Fax +82-51-245-8539 \\ E-mail swforyou@gmail.com
}

\begin{abstract}
Multiple calcification in the major salivary glands is very rare. Sjögren's syndrome is characterized by tissue damage due to chronic lymphocyte infiltration of exocrine glands, and the involvement of the major salivary glands is followed by typical symptoms such as multiple formation of sialolith, blockage of salivary duct, and edema of the parenchyme. When multiple calcification is found in the parenchyme of parotid gland on the computed tomography imaging, Sjögren syndrome should be considered, where the primary solution is conservative treatment and preventing recurrent inflammation.
\end{abstract}

Korean J Otorhinolaryngol-Head Neck Surg 2015;58(8):567-71

Key Words Parotid gland · Sialolithiasis · Sjögren's syndrome.

\section{서 론}

쇼그렌 증후군(Sjögren's syndrome)은 침샘과 눈물샘에 만성 림프구 침윤으로 인한 조직손상을 특징으로 하는 질환 으로, 타액선의 실질과 관내의 타석이 다발성으로 생기는 경 우가 존재한다. ${ }^{1,2)}$ 쇼그렌 증후군으로 생기는 타석은 주로 이하 선에서 생기고, 본 증례와 같이 이하선의 실질 내에 다발성의 석회화 소견을 보이는 것이 특징이다. ${ }^{3.4}$ 쇼그렌 증후군에서 생 기는 다발성 타석은 매우 드물기 때문에 ${ }^{3,5}$ 증례와 문헌 보고를 리뷰하여 임상적인 도움을 주고자 한다.

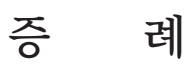

64세 여자 환자가 1 년간 좌측 이하선의 반복되는 이하선 부위의 종창과 통증을 주소로 내원하였다. 환자는 내원 1년 전부터 지속적인 구강 건조 및 안구건조 증상이 동반되었다. 이런 주증상은 주로 식사를 할 때 갑자기 생기는 전형적인 폐
쇄성 이하선염의 소견을 보였고, 이하선 부위를 마사지하면 이하선관의 개구부에서 농성분비물이 배액되면서 증상이 다 소 개선되었다. 경부 전산화단층촬영(computed tomography, $\mathrm{CT}$ )에서 좌측 이하선 실질의 종창과 실질내 다발성의 석회화 소견이 관찰되었다(Fig. 1). 쇼그렌 증후군 등의 원인질환을 감별하기 위해 류마티스 내과 및 안과와 협진을 진행하였다.

혈액검사 결과 백혈구(white blood cell)는 4200/10 L로 림 프구(lymphocyte) 비율은 52.8\%였다. 항핵항체 양성, 항-Ro 항 체 및 항-La 항체 강양성이었으며, 적혈구침강반응(erythrocyte sedimentation rate, ESR)은 $102 \mathrm{~mm} / \mathrm{hr}$ 였다. 타액선 신티그 래피 검사(salivary scintigraphy)에서는 양측 이하선 부위의 흡수 감소가 관찰되었다(Fig. 2). 쉬르머 검사(Schirmer's test) 결과, 좌안, 우안 각각 $3 \mathrm{~mm}, 4 \mathrm{~mm}$ 로 분비감소 소견을 보였 다. 쇼그렌 증후군의 진단기준 6 개 중 5 개에 해당하며 객관적 기준 4 개 중 3 개에 충족하여 쇼그렌 증후군으로 진단 가능하 여 조직검사는 시행하지 않았다(Table 1 and 2). ${ }^{1)}$

치료는 수분공급을 충분히 하면서 이하선 부위를 마사지하 


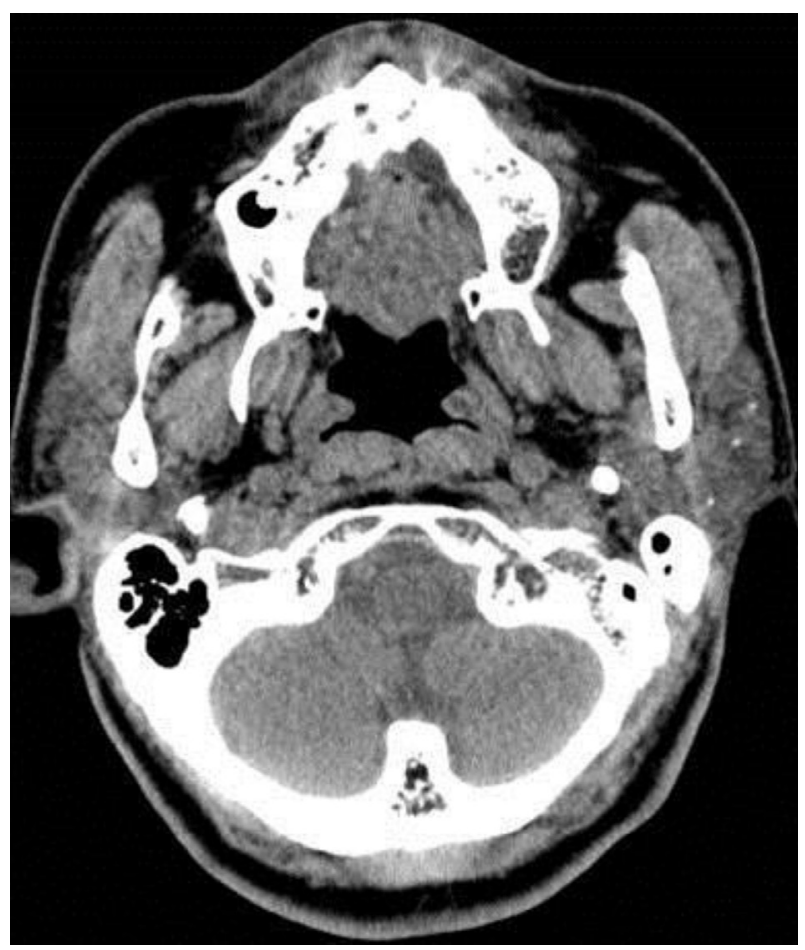

Fig. 1. Axial view of neck CT scan taken when the patient first visited. Multiple calcification was found in the parenchyme of the left parotid gland.
여 타석이 잘 배출될 수 있게 보존적 치료를 하였다. 약물치 료로는 타액분비 촉진을 위해 pilocarpine을 사용하였고, 염 증 완화를 위해 스테로이드(triamcinolone)를 병용하였다. Triamcinolone $2 \mathrm{mg}$ 및 pilocarpine $5 \mathrm{mg}$ 를 하루 2회 15일간 복용하였고 폐쇄성 이하선염이었지만 타액 배출 폐색으로 인 한 악화 없이 증상 호전을 보여 triamcinolone $2 \mathrm{mg}$ 을 하루 1 회로 줄이고 pilocarpine 용법을 유지하여 2개월 사용 후 중 단하였다. 항생제는 사용하지 않았다. 1 년이 지난 뒤에 외래 방문하였을 때는 증상이 많이 개선되었고 CT에서도 타석의 개수가 많이 감소한 것을 확인할 수 있었다(Fig. 3). 1년이 지난 현재까지 호전된 상태를 유지하고 있으며 경과관찰 중이다.

\section{고 찰}

쇼그렌 증후군은 침샘과 눈물샘에 만성 림프구 침윤으로 인한 조직손상을 특징으로 하는 질환이다. 전형적인 초기 증 상은 반복되는 구강과 안구의 건조증인데, 비특이적인 염증 을 유발하고, ${ }^{6}$ 타액선의 실질과 관내의 타석이 다발성으로 생기면서 타액선관의 폐색과 타액선 실질의 부종과 같은 증 상이 먼저 생기는 경우도 있다.,2) 일반적인 타석은 주로 악하

Fig. 2. Salivary scintigraphy result shows reduced uptake in both parotid and submandibular salivary glands, suggesting decreased function.

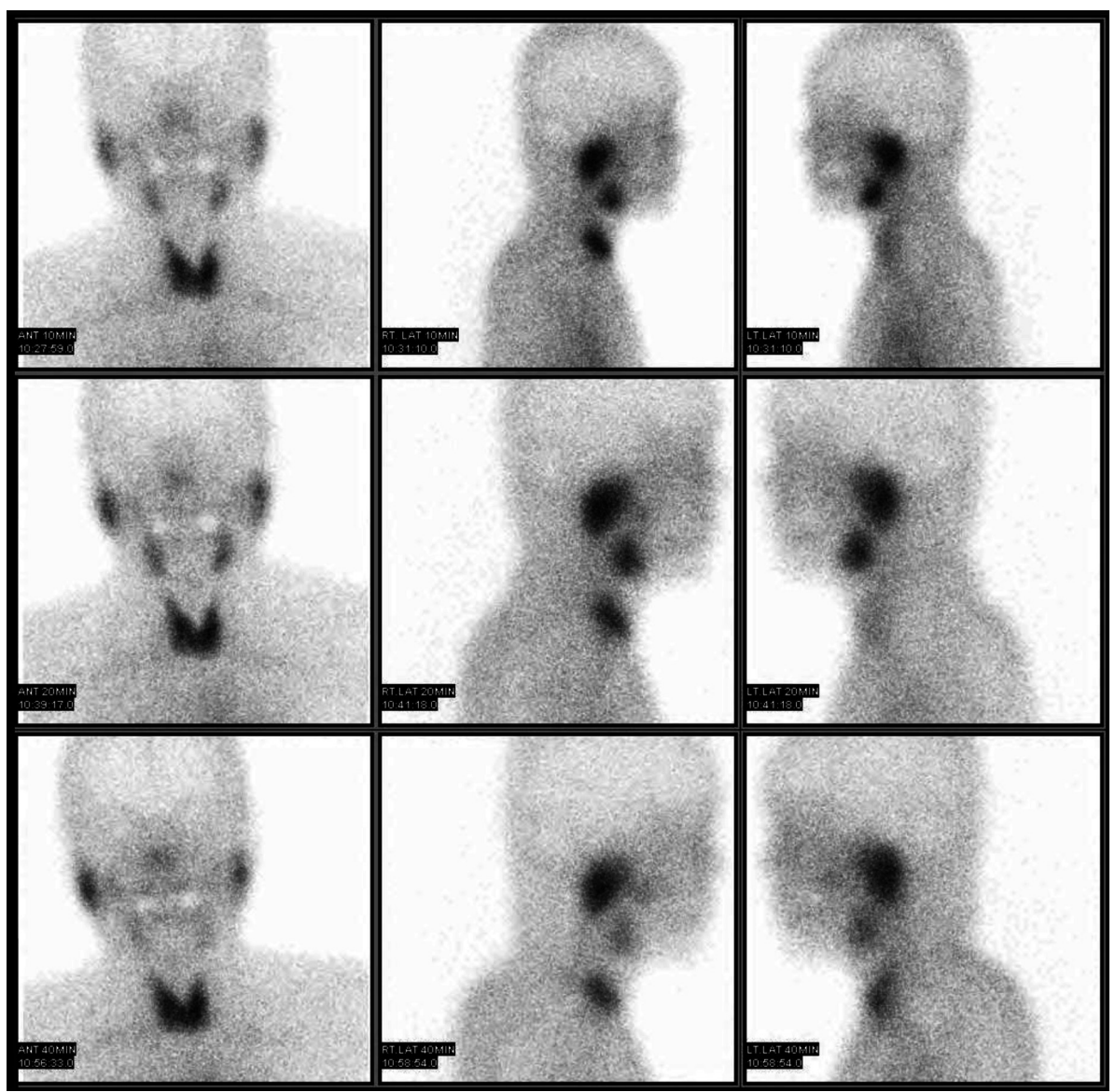


Table 1. Revised international classification criteria for Sjögren's syndrome

\begin{tabular}{|c|c|}
\hline Criterias & \\
\hline \multicolumn{2}{|l|}{ Symptoms } \\
\hline I. Ocular symptoms & $\begin{array}{l}\text { At least one of: } \\
\text { - Daily, persistent, troublesome dry eyes for more than } 3 \text { months } \\
\text { - Recurrent sensation of sand or gravel in the eyes } \\
\text { - Usage of tear substitutes more than } 3 \text { times a day }\end{array}$ \\
\hline II. Oral symptoms & $\begin{array}{l}\text { At least one of: } \\
\text { - Daily feeling of dry mouth for more than } 3 \text { months } \\
\text { - Recurrently or persistently swollen salivary glands as an adult } \\
\text { - Frequently drink liquids to aid in swallowing dry food }\end{array}$ \\
\hline \multicolumn{2}{|l|}{ Objective criteria items } \\
\hline III. Ocular signs & $\begin{array}{l}\text { At least one of: } \\
\text { 1. Schirmer's I test, performed without anaesthesia ( }<5 \mathrm{~mm} \text { in } 5 \text { minutes) } \\
\text { 2. Rose bengal score or other ocular dye score ( }>4 \text { according to van Bijsterveld's scoring system) }\end{array}$ \\
\hline IV. Histopathology & $\begin{array}{l}\text { In minor salivary glands (obtained through normal-appearing mucosa) focal lymphocytic } \\
\text { sialoadenitis, evaluated by an expert histopathologist, with a focus score }>1 \text {, defined as a } \\
\text { number of lymphocytic foci (which are adjacent to normal-appearing mucous acini and } \\
\text { contain more than } 50 \text { lymphocytes) per } 4 \mathrm{~mm}^{2} \text { of glandular tissue }\end{array}$ \\
\hline V. Sailvary gland involvement & $\begin{array}{l}\text { At least one of: } \\
\text { 1. Unstimulated whole salivary flow ( }<1.5 \mathrm{~mL} \text { in } 15 \text { minutes) } \\
\text { 2. Parotid sialography showing the presence of diffuse sialectasias (punctate, cavitary or } \\
\text { destructive pattern), without evidence of obstruction in the major ducts } \\
\text { 3. Salivary scintigraphy showing delayed uptake, reduced concentration and/or delayed } \\
\text { excretion of tracer }\end{array}$ \\
\hline VI. Autoantibodies & $\begin{array}{l}\text { In the serum of the following autoantibodies: } \\
\text { - Antibodies to Ro (SSA) or La (SSB) antigens, or both }\end{array}$ \\
\hline
\end{tabular}

Table 2. Revised rules for classification of Sjögren's syndrome

Primary SS In patients without any potentially associated disease, primary SS may be defined as follows:

a) The presence of any 4 of the 6 items is indicative of primary SS, as long as either item IV (histopathology) or VI (serology) is positive

b) The presence of any 3 of the 4 objective criteria items (that is, items III, IV, V, VI)

c) The classification tree procedure represents a valid alternative method for classification, although it should be more properly used in clinical-epidemiological survey

Secondary SS

In patients with a potentially associated disease (for instance, another well defined connective tissue disease), the presence of item I or item II plus any 2 from among items III, $\mathrm{IV}$, and $\mathrm{V}$ may be considered as indicative of secondary SS

Exclusion criteria

Past head and neck radiation treatment

Hepatitis C infection

Acquired immunodeficiency disease (AIDS)

Pre-existing lymphoma

Sarcoidosis

Graft versus host disease

Use of anticholinergic drugs (since a time shorter than 4-fold the half life of the drug)

\section{SS: Sjögren's Syndrome}

선에서 생기지만, 쇼그렌 증후군과 관련된 타석은 주로 이하 선에서 생기며 원인은 알려져 있지 않다. ${ }^{6)}$ 중증의 쇼그렌 증 후군에서는 타석이 본 증례와 같이 다발성으로 생기는 것이 특징이다. ${ }^{3)}$ 또한 이전에 타액선염에 대한 병력이 없었고, 반 복되는 타액선염으로 인한 결석이 없었던 과거력도 자세한 문진을 통해 배제해야 한다. ${ }^{4)}$ 본 증례에서는 약 1 년 전부터 지속적인 구강건조 및 안구건조 증상이 있었으며, 동위원소 검사, 자가항체 검사 및 쉬르머 검사를 통해서 쇼그렌 증후 군으로 진단되었으며, 반복적인 이하선의 염증 소견 및 이하
선의 다발성 타석을 발견할 수 있었다.

쇼그렌 증후군에서 생기는 타석에 대한 유병률을 조사한 문헌 보고는 없지만, 이하선에서 다발성 타석에 대한 보고는 매우 드물다. ${ }^{3,5}$ 또한 일반적으로 타석이 생기는 기전은 타액 의 흐름이 줄어들고, 타액에 칼슘과 염분이 고농도로 있으면 서 유기적인 기질 성분과 혼합되어 생성된다고 알려져 있지만, 쇼그렌 증후군에서 타석이 다발성으로 생기는 이유가 명확하 게 설명된 보고는 없다. ${ }^{6}$

외분비선에서 조직검사를 해보면 특징적인 분비샘의 림프구 


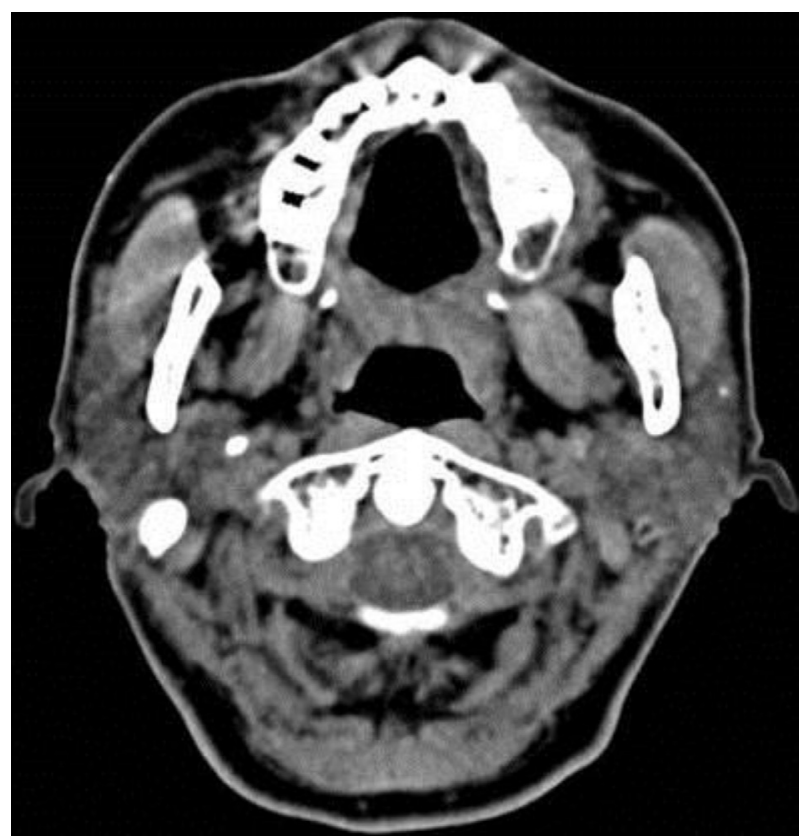

Fig. 3. Axial view of neck CT scan 1 year after the first visit showed decreased number of the sialoliths in the parotid glands.

침윤이 있으며, 혈청 감마 글로불린 증가, 적혈구 침강률(ESR) 증 가, SS-항원 A와 B에 대한 항체(anti-SS antigen A and B), 항핵항체(antinuclear antibody), 류마티스인자(rheumatoid factor) 등이 양성이다.1) 쇼그렌 증후군에서 드물지만 이하선 종양으로 발생하는 점막관련 림프조직 종양[mucosa-assisted lymphoid tissue(MALT) lymphoma]이 생길 가능성이 증가 되기 때문에 주의하여 관찰하여야 한다. ${ }^{8)}$

$\mathrm{CT}$ 검사를 하면 다발성으로 석회화된 타석과 급성 이하선 염을 쉽게 확인할 수 있고, MALT 림프종이나 가성종양이 있 는지도 감별할 수 있어서 유용하다고 알려져 있으며, ${ }^{6}$ 본 증 례에서도 초음파 및 CT를 통해 종양은 배제할 수 있었으며, 다발성 타석을 확인할 수 있었다.

침샘염의 급성기에는 검, 사탕 등의 타액분비촉진제(sialogogues)가 도움이 되고, 수분공급, 온열 압박마사지가 도움이 된다. 특히 이하선을 잘 촉지하고, 마사지를 잘해서 타석이 이하선관 개구부를 통해 구강으로 빠져나오는 것을 확인하 여 증상이 빨리 개선되었다는 보고가 있다.) 본 케이스의 경 우 마사지를 교육하여 시행하였지만 타석이 나오지는 않았 다. 약물치료는 급성기에는 항생제, 항염증제, 진통제 등을 사용하고, 장기적으로는 쇼그렌 증후군에 대한 치료를 하여 야 한다. ${ }^{6}$

대증요법에 대한 치료가 효과가 없다면, 수술적 치료를 하 기도 한다. 최근에는 수술적 치료로 침샘관내시경이나 침샘 조영술을 하면서 바스켓(basket)을 이용해 타석을 제거하는 방법이 소개되고 있는데, ${ }^{910)}$ 결석이 이하선관이나 문(hilum)
근처에 있는 경우라면 결석을 제거하는 데 유용하지만, 결석이 이하선의 실질에 있는 경우에는 적용되기 어렵고, 결절의 크기 가 $5 \mathrm{~mm}$ 이상이면 이하선관을 통해 결석을 제거하기 어렵다 는 제한이 있다. 또 다른 방법은 초음파를 하면서 충격파 쇄 석술을 하는 것인데, ${ }^{11)}$ 결석의 위치, 크기, 개수에 상관없이 유 용하게 사용될 수 있고, 반복 시술이 가능하다는 것도 장점이 다. 하지만, 충격파 쇄석술을 하면 증상이 완화되는 경우는 $80 \%$ 정도이지만, 결석이 제거되는 경우는 $50 \%$ 정도로 낮다 는 점도 고려하여야 하고, 충격파가 이하선의 실질에 손상을 주어 섬유화를 유발할 수 있다는 단점이 있다. ${ }^{12}$ 그리고, 고실 신경 절단술 등을 하기도 한다. ${ }^{13)}$ 침샘을 제거하는 수술이 근 본적인 치료이긴 하지만, 중요한 신경 손상 등의 침샘제거수 술로 인한 심각한 합병증이 있을 수 있으므로 마지막에 선택 되는 술식이며 일측의 이하선의 결석이 3개 이상 있고, 반복되 는 이하선염의 병력과 침샘관 내시경이나 충격파 쇄석술로 치 료되지 않는 경우에 고려해 볼 수 있다. ${ }^{12}$ 동물모델에서 고칼 슘혈증이 타석 생성의 원인일 수 있다는 보고도 있지만, ${ }^{14)}$ 인 간에서는 증명된 바가 없어서 예방적으로 칼슘이 많이 함유 된 음식을 주의할 필요는 없다.)

본 증례와 같이 이하선 종창이 있고, CT 검사에서 다발성 석회화 소견이 관찰되면, 쇼그렌 증후군을 감별 진단해야 한 다. 그리고, 수술적 치료보다는 대증적인 치료와 반복되는 염 증을 예방해주는 것이 필요하다.

\section{REFERENCES}

1) Vitali C, Bombardieri S, Jonsson R, Moutsopoulos HM, Alexander EL, Carsons SE, et al. Classification criteria for Sjögren's syndrome: a revised version of the European criteria proposed by the AmericanEuropean Consensus Group. Ann Rheum Dis 2002;61(6):554-8.

2) Nahlieli O, London D, Zagury A, Eliav E. Combined approach to impacted parotid stones. J Oral Maxillofac Surg 2002;60(12):1418-23.

3) Shimizu M, Yoshiura K, Nakayama E, Kanda S, Nakamura S, Ohyama Y, et al. Multiple sialolithiasis in the parotid gland with Sjögren's syndrome and its sonographic findings--report of 3 cases. Oral Surg Oral Med Oral Pathol Oral Radiol Endod 2005;99(1):85-92.

4) Zenk J, Gottwald F, Bozzato A, Iro H. [Submandibular sialoliths. Stone removal with organ preservation]. HNO 2005;53(3):243-9.

5) Wickramasinghe A, Howarth A, Drage NA. Multiple bilateral parotid sialoliths in a patient with mucosa-associated lymphoid tissue lymphoma (MALT lymphoma) of the salivary glands. Oral Surg Oral Med Oral Pathol Oral Radiol Endod 2005;99(4):496-8.

6) Konstantinidis I, Paschaloudi S, Triaridis S, Fyrmpas G, Sechlidis $\mathrm{S}$, Constantinidis J. Bilateral multiple sialolithiasis of the parotid gland in a patient with Sjögren's syndrome. Acta Otorhinolaryngol Ital 2007;27(1):41-4.

7) Boynton TT, Lieblich SE. Unusual case of a sialolith: a case report. Oral Surg Oral Med Oral Pathol Oral Radiol 2014;117(1):e9-10.

8) Voulgarelis M, Dafni UG, Isenberg DA, Moutsopoulos HM. Malignant lymphoma in primary Sjögren's syndrome: a multicenter, retrospective, clinical study by the European Concerted Action on Sjögren's Syndrome. Arthritis Rheum 1999;42(8):1765-72.

9) Drage NA, Brown JE, Escudier MP, McGurk M. Interventional 
radiology in the removal of salivary calculi. Radiology 2000;214 (1):139-42

10) Durr ML, George JR, Meyer AK, Rosbe KW. Sialendoscopy for recurrent parotitis associated with Sjogren syndrome: a case report. Int J Pediatr Otorhinolaryngol Extra 2011;6(4):291-3.

11) Ottaviani F, Capaccio P, Campi M, Ottaviani A. Extracorporeal electromagnetic shock-wave lithotripsy for salivary gland stones. Laryngoscope 1996;106(6):761-4.

12) Iro H, Schneider HT, Födra C, Waitz G, Nitsche N, Heinritz HH, et al. Shockwave lithotripsy of salivary duct stones. Lancet 1992;339
(8805):1333-6.

13) Hackett AM, Baranano CF, Reed M, Duvvuri U, Smith RJ, Mehta D. Sialoendoscopy for the treatment of pediatric salivary gland disorders. Arch Otolaryngol Head Neck Surg 2012;138(10):912-5.

14) Westhofen $M$, Schäfer $H$, Seifert G. Calcium redistribution, calcification and stone formation in the parotid gland during experimental stimulation and hypercalcaemia. Cytochemical and X-ray microanalytical investigations. Virchows Arch A Pathol Anat Histopathol 1984;402 (4):425-38. 